IOH N SLOA N

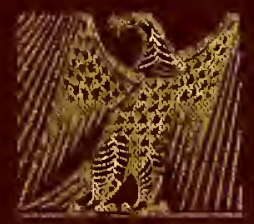

A MERIEAN ARTISTE SERIES

QFITNEX MUSELM CF AMERICAN ART 


\section{.}





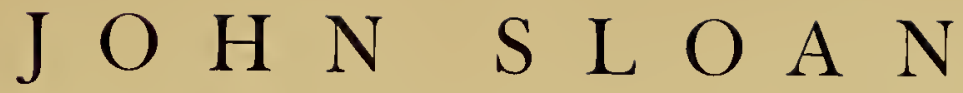

BY

\author{
GUY PÈNE DU BOIS
}
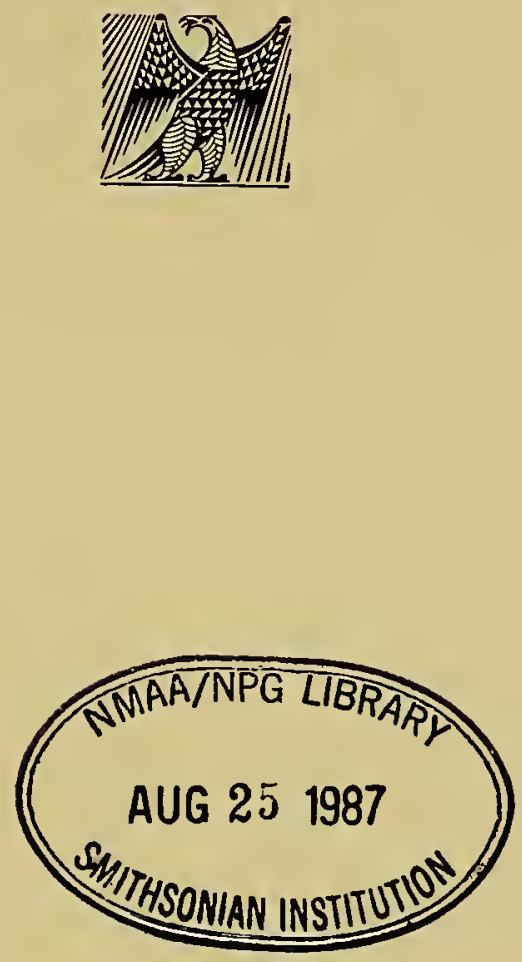

$A M E R I C A \mathcal{N} A R T I S T S$ SERIES

WHITNEY MUSEUM OF AMERICAN ART

TEN WEST EIGHTH STREET - NEW YORK

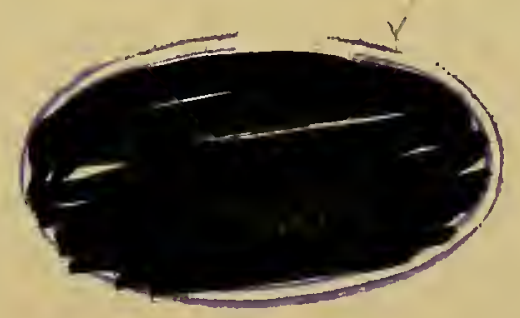




\section{TITLES OF BOOKS IN THIS SERIES ALREADY PUBLISHED}

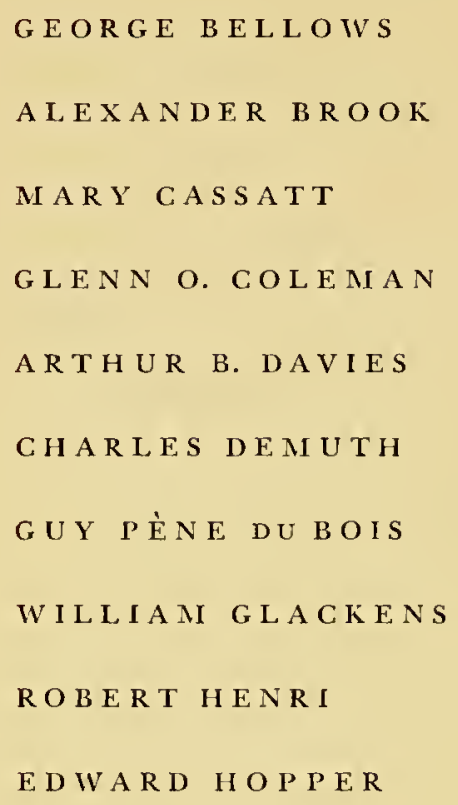

\section{IN PREPARATION}

THOMAS H. BENTON

CHARLES B URCHFIELD

PRESTON DICKINSON

ER NEST FIENE

WALT KUH N

\author{
GASTON LACHA ISE \\ JOHN MARIN \\ BOARDMAN ROBINSON \\ CHARLES SHEELER \\ W I L L I A M Z O RACH
}

And others 


\section{GONTENTS}

PAGE

FORE WORD

Portitit of The ARtist

Joh n Soan. By Guy Pène du Bois . . . . . . . . 7

BIOGRAPHICAL NOTE . . . . . . . . 14

BIBLIOGRAPHY

ILLUSTRATIONS

Publication of the books entitled

MARY CASSATT, GLENN O. COLEMAN and

ALLEN TUCKER has been postponed.

These volumes will appear in 1932. 


\section{F O R E W O R D}

TH Is book is one of a series devoted to the work of various American artists and is published by the Whitney Museum of American Art, founded by Gertrude V. Whitney. The purpose of these books, like that of the Museum which sponsors them, is to promote a wider knowledge and appreciation of the best in American art.

For assistance in preparing this volume for publication, we wish gratefully to acknowledge our indebtedness to the Kraushaar Galleries for information regarding paintings used for illustration, to The Arts magazine for the loan of its files of photographs, and to the museums and private collectors whose paintings, reproduced in this book, add so notably to the value of the illustrations.

JuLIANA R. Force, Director Whitney Museum of American Art 


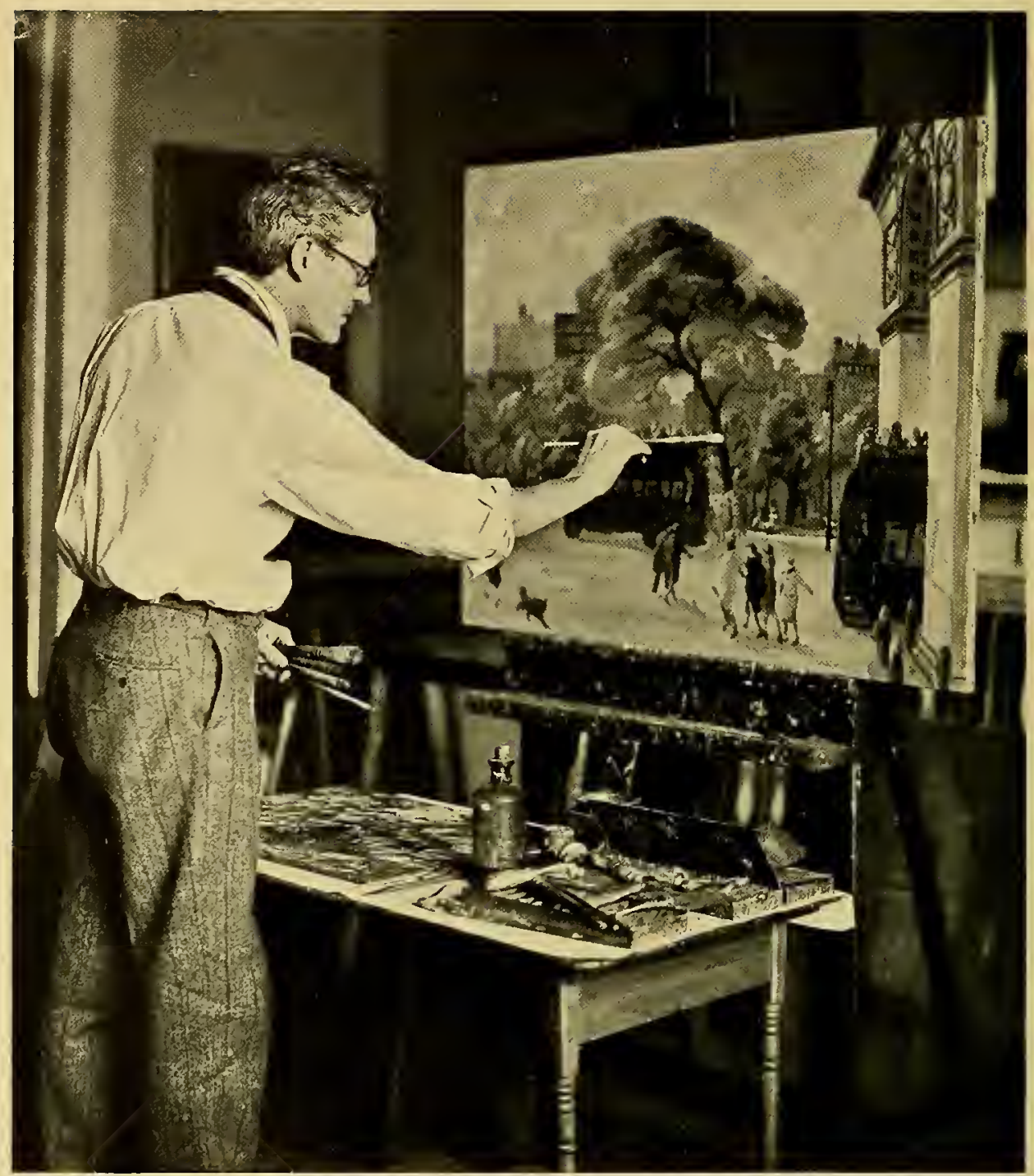

Photograph by A. B. Bogari

JOHN SLOAN 


\title{
JOHN SLOAN
}

B Y

\author{
GUY PÈNE DU B O IS
}

I $\mathrm{T}$ is tempting to say of John Sloan that if his interest in life were to be placed on one pan of a scale and his interest in art on the other the latter would be greatly over-balanced by the former. But this simple statement, like most simple statements, is untenable. It could not be allowed to stand without taking account of the comparative factors by which the temptation to make the statement was, in the first place, aroused. The balance with most painters, and most painters are unimportant, as we all know, would fall on the side of art. And taking the two examples together immediately demands a discussion of art versus life with all the involutions and misunderstandings which this discussion usually creates.

It would become necessary to begin at the beginning of the history of art, to remind of the first known drawing made by man, the well known buffalo which he scratched on the walls of his cave, somewhat wantonly, as we might think today, in order to show his appreciation of the beauty of nature. Was it for this reason? Then we should have to travel down the long path to where man becoming sophisticated or conscious and certainly weaker began to use his mind more and his impulse less, began, to cut it short, to think upon aesthetics. This might mean in the artist a reversion to simian characteristics. It could work that way, for where the scales fall on the side of art we are certain to find a move away from life, from that impulse which created the first drawing to that notion which causes man to collect pictures and one artist to imitate another. The ground, even when so hurriedly traversed as this, immediately begins to suggest the presence of pitfalls. The greatest of these is labeled "What is art?"- - question whose answers all deny each other. There is not room enough for a comprehensive reply to it here or anywhere. 
Certainly the fashionable dictum of today will be the fashionable horror of tomorrow. Of all those that have gone in the past the most constantly recurring one-perhaps because it is the most enigmatic-is art for art's sake. Its appeal to the conscious artist, when taken literally, is romantic and valiant. It lends him a suggestion of purity, makes him feel, when he pursues it, uncontaminated, a knight, on a disinterested adventure. In reality, to which we must always unfortunately descend, it destroys whatever valid reason for being his art could have. Certainly no living thing can feed upon itself and if art is not the result of an interest in life then it must be motivated by an interest in art. Nothing is built without the use of extraneous material. If the artist turns to art then he must borrow lock, stock and barrel from the work of other men, be, instead of an artist, an admirer of other artists, a dilettante.

Sloan is most assuredly not in this category. He is a man who talks on the life which interests him, simply, directly, and, one might almost say, unconsciously. His paint might make one think of ordinary conversation but this only when it is compared to the rhetorical flourishes of some of the old Daniel Websters of paint or to the elegantly balanced periods of those precious little fellows who have, for fear of contamination, turned their backs on life forever. I cannot remember a still life by Sloan. He would, I am sure, have been lost as an artist during the period of the dictatorship of the Nicene Fathers when the "Thou shalt not make a graven image" edict was so rigidly enforced. He devotes his art entirely to things he has seen in life; makes his art the servant of life. He is never caught turning one of those somersaults in paint by which the conscious technician detracts from the thing he is talking about by accentuating the way he is talking.

Sloan's subject matter is more various than that of most painters. But he will never be found moved to paint a subject because of so abstract a consideration as the beauty of its color. He is not, this might mean, moved at all by flowers. He is most certainly not a decorative painter. 
He has often been accused of mixing too much literature with his paint. This, especially in recent years, since artists have become so conscious of aesthetics and, forgetting to take another look at the great painting of the past or at life, erected a score of verbotens for themselves and others. These, the so much healthier masters could never have considered at all. Perhaps artists would do better leaving aesthetics, more useful after than before the fact, to the critics and the picture experts and collectors who are amused by their involutions and never do much damage anyway, since they must talk on a fait accompli. If literature should not appear in paint then practically all the painters from Hogarth back to Giotto have been horribly mistaken.

"If it were not for the poets," said that old Irish philosopher, the late John B. Yates, "no one would know that the spring was beautiful." If it were not for such seers as John Sloan, and a few French realists, we would still be going under the terrible delusion that our women resembled the insipid goddesses of the old French Salon or the much too chaste papier mâché spinsters of our own National Academy of Design. Perhaps vision wants more educating than the other senses. On this I am not competent to judge, my own having, probably, been overtrained. Still I wonder if any casual observer ever sees a blue hill in nature before having seen one in paint. I wonder too, to jump around a little, if Tenniel's pictures of the characters in Alice in Wonderland have not made them live more concretely for us than those written by Lewis Carroll. It is certainly a fact that the exaggerated drawings of the caricaturists help to define a personality with more economy than those of the writer. Writing cannot go very readily to a visual resemblance. The way is a tortuous one and must end, at best, by demanding some building ability in unskilled eyes. If this were not true the popularity of the tabloids would be inexplicable.

Sloan's talk on life by which his painting is actuated, to which it is a valet, ready, if you like, for the emergency but never predominating it, 
is equal in profundity and extent to Theodore Dreiser's and has indeed, in realistic intention, some resemblance to it. This, despite that one must work from the inside to the outside hoping that the rendering of the interior will make possible a realization of the exterior and the other is forced, of course, to reverse the process. The fact that these two men are very much of the same period, were both caught in the wave of realism which came as a reaction to the sentimental romances so prevalent in the painting and writing of the nineties, may account for this comparison more than anything else. And though as realists both have talked of formally forbidden subjects, stepped out of conventional paths into similar outlaw places, any intimate examination of them will destroy their resemblance immediately. The heavy-handedness of Dreiser, so easily becoming awkward, the ugliness which he finds and feels in life does not exist with Sloan. Where one will sometimes seem to be moved to write by a kind of hatred of the thing he deals in, a protestant revelation, a kind of exposer's zeal; the other is moved by love and love or liking alone. Where Dreiser might be said to live with his people scourging them with the heavy lashes of his reformer's truths, Sloan is a little aside, an observer watching the ants play through a magnifying glass and marveling at their so very human characters and contours without ever, in any real sense, becoming involved himself.

Sloan has been accused of being a Socialist by people who have heard him talk or have remembered that he was once associated with that radical magazine The Masses. Nothing could be more unfair to the painter, although I can easily imagine the man in argument, with quite unconscious sentimentality, taking the side of the people, his children or his world which he portrays. He is definitely of the realist contingent, a lover of, this means, bare fact and a detester of affectation. He would have people shorn of those masques by which they erect class distinctions or are enabled, when snobs, to more bravely face the world. The only instances in which he has been aroused to satire, and then never 
severely, have been when he was dealing with the socially elect. He will be satirical about Fifth Avenue and dangerously near to romantic about Sixth. His Fifth Avenue people give you the feeling that they have just moved over from Sixth and made themselves funnier than they were by the addition of more exaggerated clothes and manners; have moved out of reality into a world of fiction. The modern realist has invariably gone about removing disguises, or disparaging them. Where Goya made his queen look a slattern, more than ever a hag, in contrast to all the magnificence of her royal regalia, Toulouse-Lautrec, himself of the nobility, went to places where character in a kimono was baldly presented to his eyes-viciousness unberibboned.

Sloan is gentler than either of these men, really nearer Courbet than either of them, a lover, one might say, of human weakness or of the truly human arabesque. He will do the fat girl in the shoddy kimono with more love than the Fifth Avenue queen because one gives in to nature quite honestly and the other fights it with all the willful devices of conscious civilization. This question of the beauty of "nature unadorned" over the adorned one will never be satisfactorily settled. Sentimentality is involved on both sides. But Sloan, in any case, likes his people plain or honest or straightforward. Even then he will seek to catch them in their most unwary moments, any possible guards down: hanging the wash on a roof, cooking a late supper in a nightgown, reading a Sunday paper on a hot morning in the deshabille of the surety of no visitors or turning out the light on the moment of going to bed. His intimate scenes are really very intimate. In the street scenes, especially the earlier New York ones, there will always be some incidental comment on the human comedy. A memorable one shows a little girl with her chest held competitively out as she passes a dress form in a window display. His pictures of the Sixth Avenue of "growler" days hold many such incidents. But they are part of a scene treated in a pictorial way, as a study, since he is a realist, of the character of the scene, the crowd and here and there of 
its individual units. He has never devoted a complete painting to a story as Rembrandt did in his biblical illustrations nor ever made a picture in order to show how tastefully he could arrange lines and colors. He is essentially an easel painter.

His painting may be divided into three periods: New York, Gloucester and Santa Fé. He went to Gloucester in 1914 when the first landscapes began to appear from his brush, and then to Santa Fé in 1919. But since he spends every winter in New York the scenes from this city continue to make intermittent appearances. His first exhibited picture Independence Square, Philadelphia was painted about 1900 and shown then at the Carnegie Institute in Pittsburgh. He came to live in New York City for the first time in 1905 . He had prior to this time been working for some years on Philadelphia newspapers as a draughtsman. The practice in drawing which he thus received may account for the real felicity of his drawing. His place in the annals of American etching is enviable. He was for many years the only one of our etchers to do figures in their natural environments as people rather than as lay dummies used to show the scale of a much more handsomely treated building. It is to him more than to any other individual that we owe the move away from the purely architectural subject which has taken place in recent American etching. But any exhaustive writing upon his etching would require much more space than can be devoted to it here and take some attention away from the painter whom we are now considering.

He has, in the past year or two, painted a series of nudes which, as studies in form, have a power rarely met in American essays on this subject. They are done generally, in the way that is almost invariable with him, with no effort at pictorial arrangement, without picturesqueness. There are in them no eye capturing arrangements, none of the devices of the decorator. One feels that the model having just come into the studio has been asked to lie there or to sit here and that the picture, with no further bother, was then started. These nudes may indeed be the clue 
to the rest of the painting. They are treated as models because they are models. They are not asked to pose as Diana or as Suzanne or as a young woman who has just stepped out of a bath into the pristine purity of a cretonne covered room. Any dishonesty, any affectation is unbearable to Sloan. Beauty is in honesty, which is, after all, truth. 
John Sloan was born in Lock Haven, Pa., August 2nd, 1871, of American parentage. His family moved to Philadelphia in 1878 where he was educated in the public schools. His study of art commenced at the Spring Garden Institute and he later worked at the Pennsylvania Academy of the Fine Arts under Thomas P. Auschutz (who was a colleague of Thomas Eakins). Twelve years of work followed on newspapers as illustrator for the Philadelphia Enquirer and the Philadelphia Press. During this period he formed a close friendship with Robert Henri which endured until the latter's death in 1929 . In 1905 he discontinued newspaper work and came to New York where he began magazine and book illustration, producing many etchings and drawings for a de luxe edition of the works of Paul de Kock.

In 1908 he formed the group known as "The Eight," whose members -Sloan, Glackens, Luks, Shinn, Lawson, Henri, Davies and Prendergast-were pioneers in the movement for freedom in art. He was prominent in organizing the Society of Independent Artists in 1917, and since 1918 has been its president. From 1914 to 1924 he taught at the Art Students' League in New York and was elected president of that organization in $193^{\circ}$.

He works in his studio in Washington Square, New York, painting and etching subjects of city life, except for four months of the year which he spends in New Mexico where he paints the Indian life and landscape of the Southwest.

His work has been shown in all the national and international exhibitions and has received the following awards: Honorable Mention, Carnegie International Exhibition, Pittsburgh, Pa., 1905; the Beck Medal for Portraiture, Pennsylvania Academy of the Fine Arts, 1931; Medal for Etchings, Panama Exposition, 1915; and the Medal for Etchings, Sesquicentennial Exposition, Philadelphia, Pa., 1926. 
He is a member of the Independent Artists, National Institute of Arts and Letters, Associate Taos Society of Artists, Society of Painters, Gravers, and the New Mexico Painters.

He is represented in many private collections and the following public institutions: Metropolitan Museum of Art; Brooklyn Institute of Arts and Sciences; Phillips Memorial Gallery, Washington, D. C.; Detroit Museum of Art; Harrison Gallery, Los Angeles, Calif.; Art Institute of Chicago; San Diego Museum; Barnes Foundation, Merion, Pa.; Museum of Art and Archaeology, Santa Fé, New Mexico; Pennsylvania State College; New York Public Library; Cincinnati Museum of Art; Newark Public Library; Carnegie Institute, Pittsburgh, Pa.; and the Whitney Museum of American Art, New York, N. Y.

\section{B I B L I O G R A P H Y}

"The Realism of John Sloan," by William B. McCormick, Arts and Decoration, 1915 -v. 5, pp. $39^{0}-39^{1}$; illus.

“John Sloan," by A. E. Gallatin, New York, 1925, 20 pp., 34 pl.

"John Sloan and the Philadelphians," by Edward Hopper, The Arts, April, 1927-v. 11, pp. 168-178; illus.

"The etchings of John Sloan," by Walter Pach, Studio, August, 1926v. 92 , pp. $102-105$ incl. illus. and 2 pl.

"An exhibition in print of the work of John Sloan," Arts and Decoration, 1916 -v. 6, pp. 142-143; illus.

"The Modern Tendency in Henri, Sloan and Bellows," by C. B. Ely, Art in America, 1922-v. 10, pp. 132-143; 4 pl.

"Certain Contemporaries; a set of notes in art criticism," by A. E. Gallatin, 1916 , pp. 23-3o. 
"The real drama of the slums, as told in John Sloan's etchings," by Charles Wisner Barrell, The Craftsman, 1909-v. 15, pp. 559-564; illus.

“The etchings, lithographs and drawings by John Sloan," by A. E. Gallatin, International Studio, 1916-v. 58, pp. xxv-xxviii; illus.

"The All-American Nineteen," by Forbes Watson, The Arts, Jan., 1930 —v. 16, pp. 300-311.

"Two famous paintings by John Sloan from the G. O. Hamlin Coll.," Arts and Decoration, Feb., 1924 -v. 20, p. 27.

"John Sloan in the Printroom," by Frank Weitenkampf, American Magazine of Art, Oct., 1929-v. 20, pp. 554-559; illus.

"Sloan advocates a Ministry of Art," American Magazine of Art, May, 1930.

$$
\begin{aligned}
& \text { ARticles by } \\
& \text { JOHN SLOAN }
\end{aligned}
$$

"The Independent, an open door," by John Sloan, The Arts, April, 1927 —v. 11 , pp. $187-188$.

“My recent encounter," by John Sloan, Creative Art, May, 1928-v. 2, pp. xliv-xlv. 


\section{LLUSTRATION S}


Corpus Christ Procession

SANTA FÉ, 1930

H. 26 inches $\quad$ w. 35 inches

18 


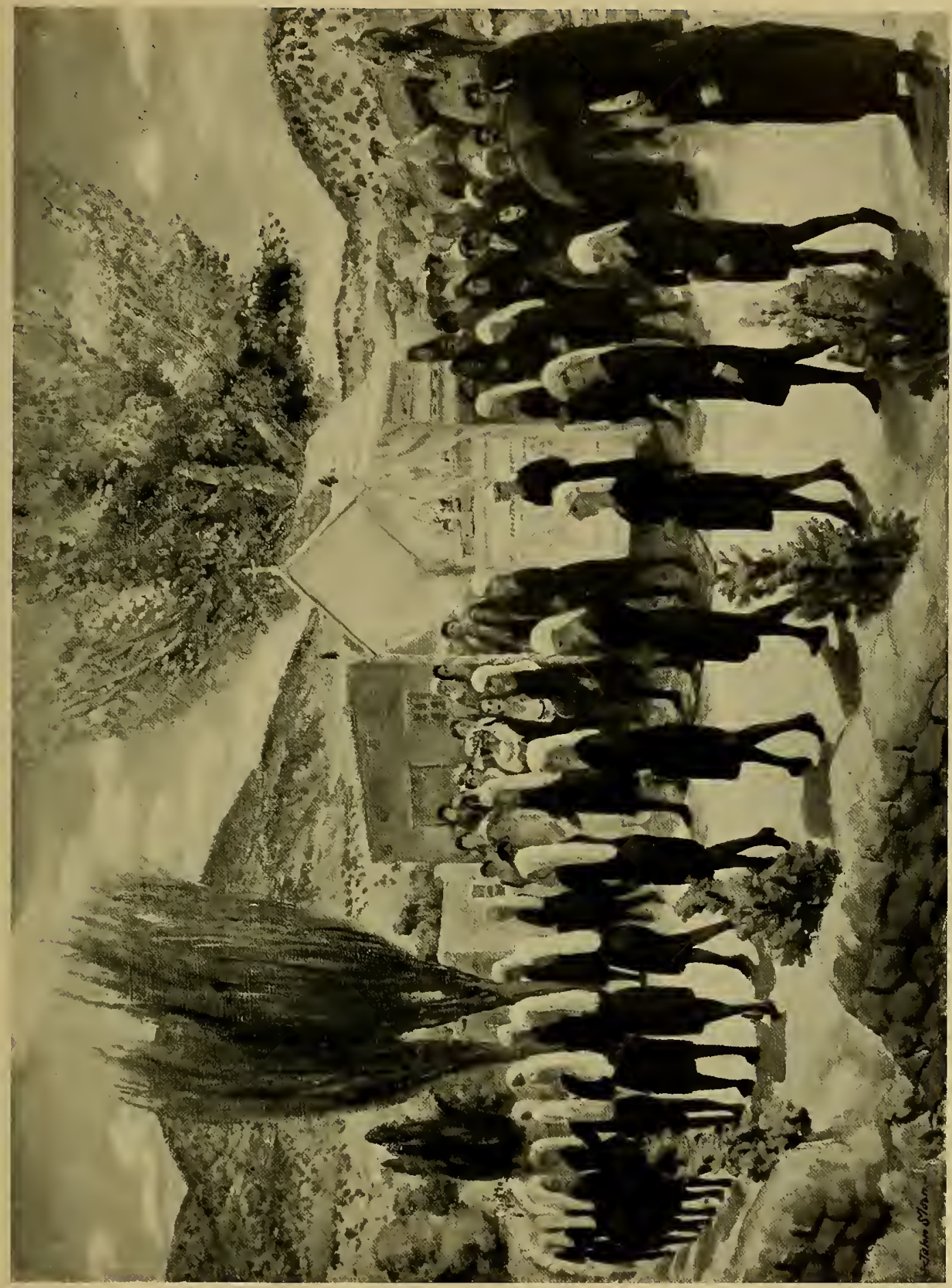


The Sculptor, Vagis, 1930 H. 24 inches W. 30 inches

20 


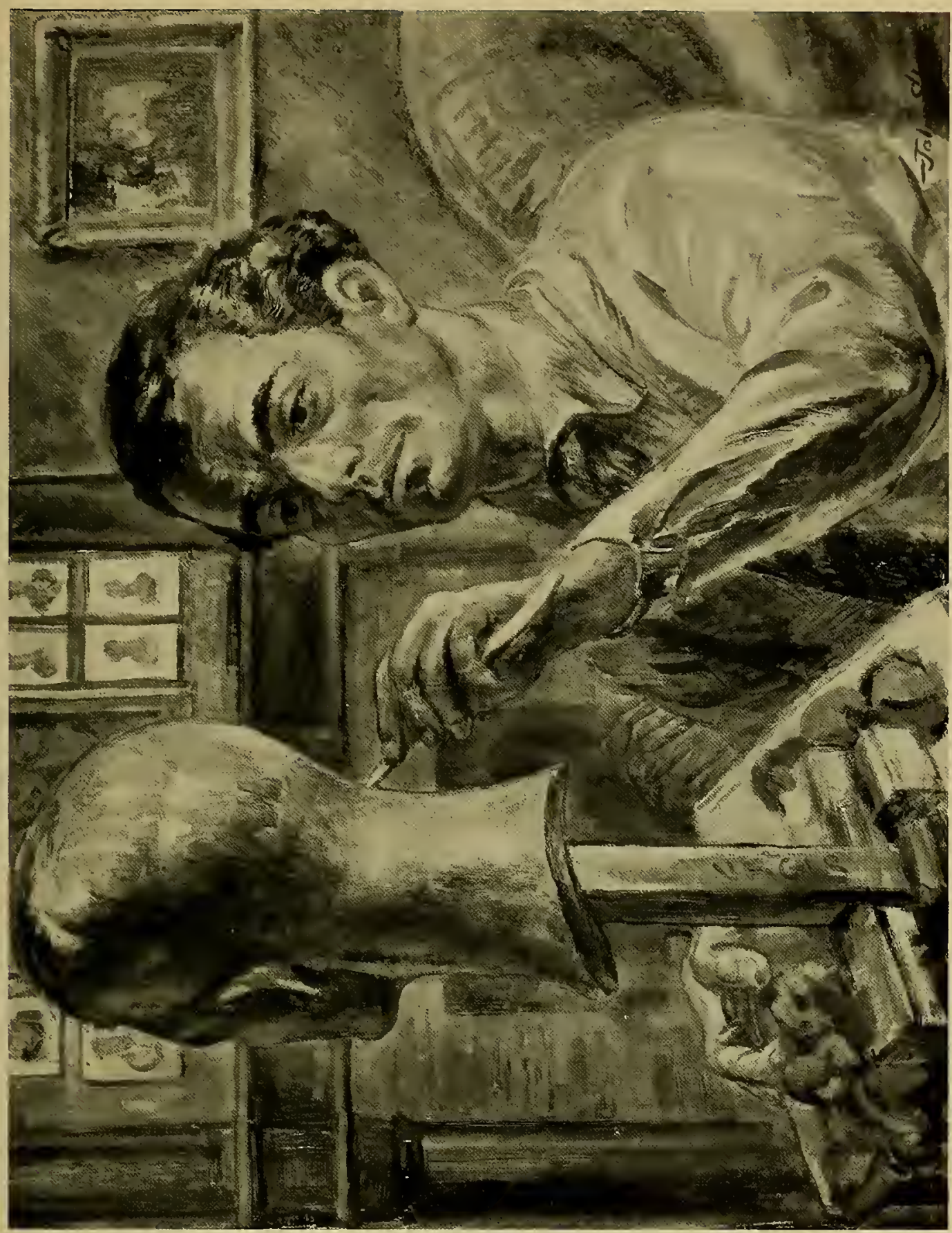


NUde ON NaVAJO BLANKET, 1929

H. 24 inches W. 48 inches

22 


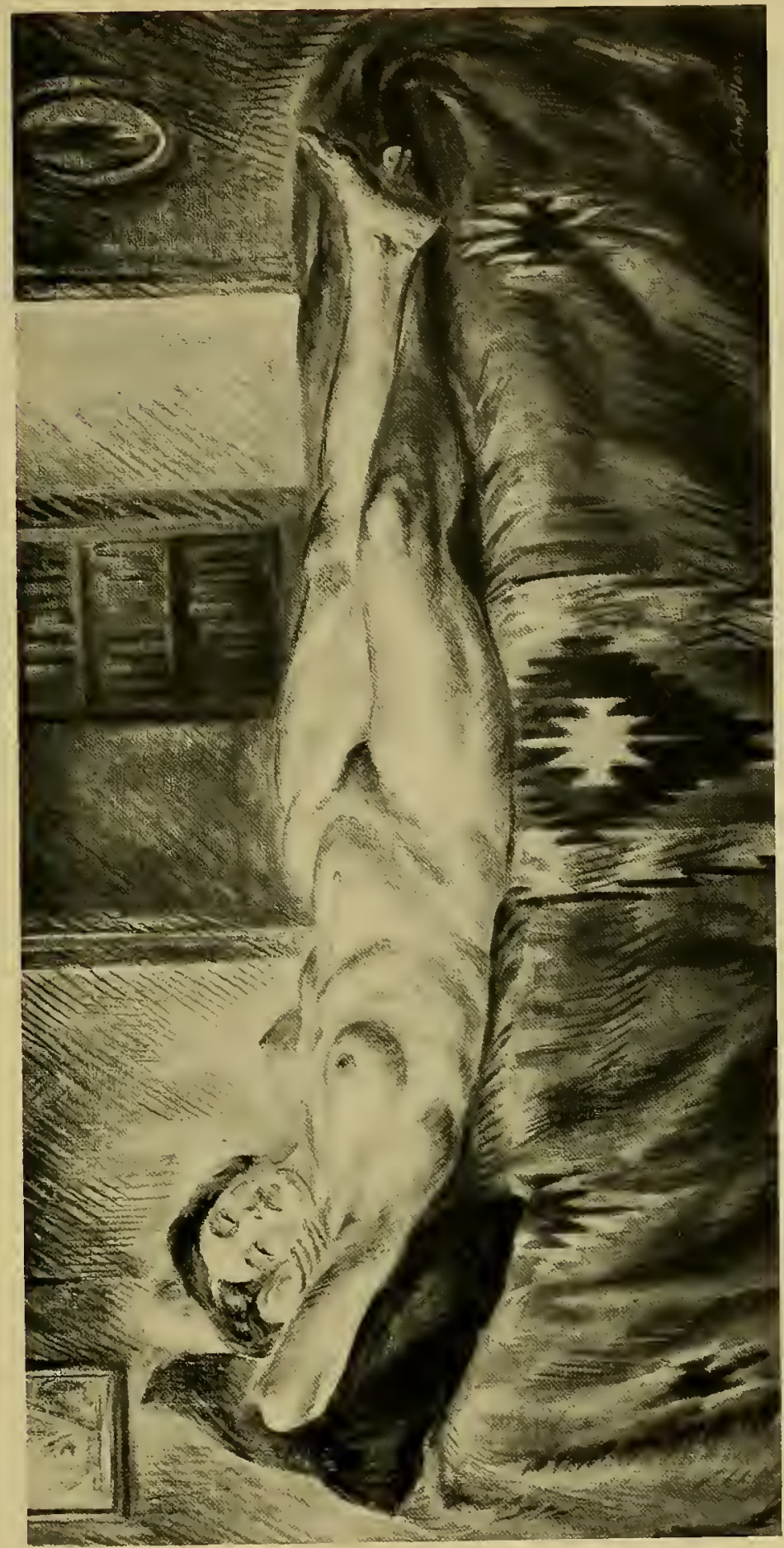


Sixth AVEnue Elevated

AT THIRD STREET, 1928

H. 30 inches W. 40 inches

24 


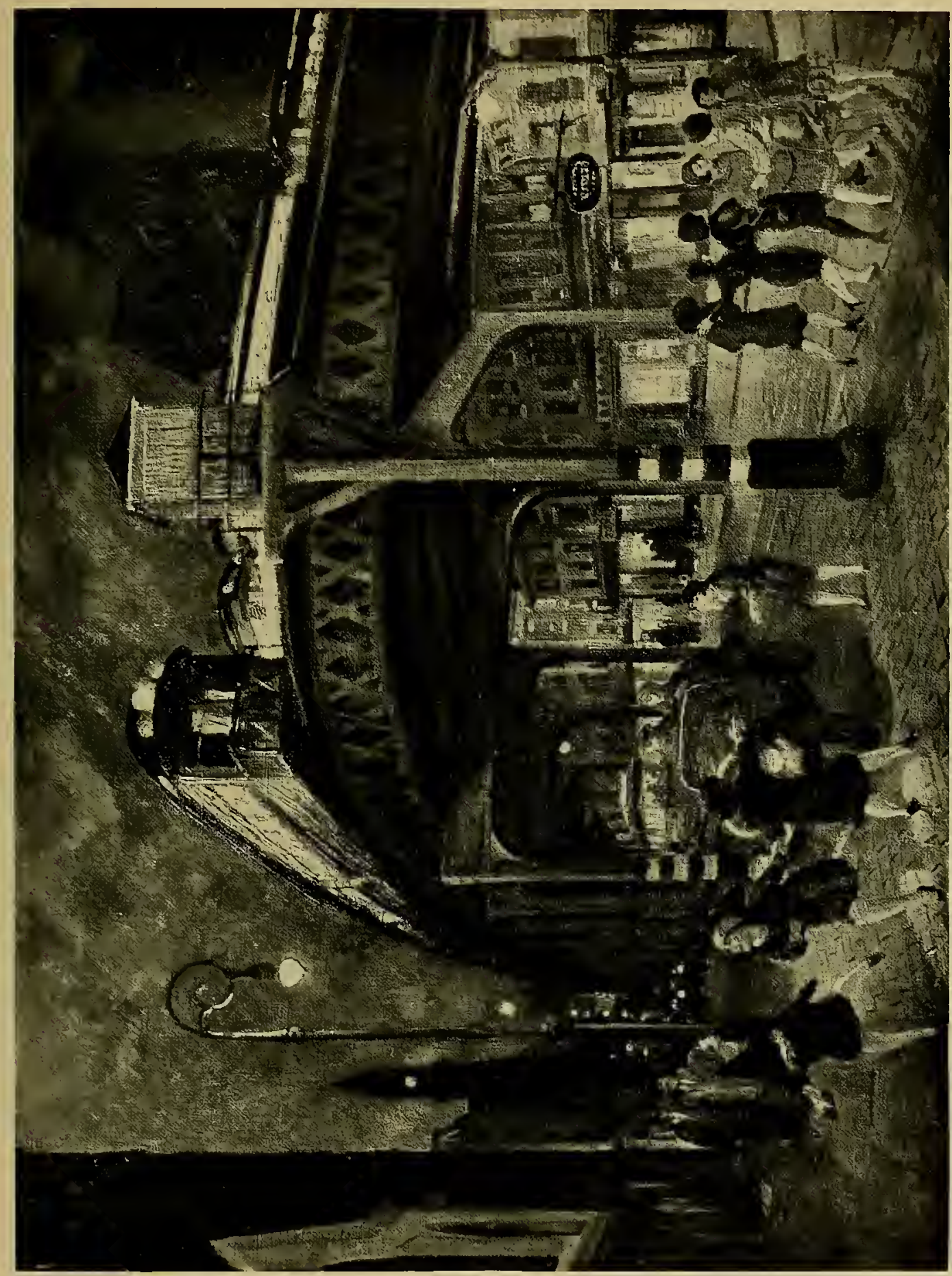


Hotel LaFayette, 1928

H. $301 / 2$ inches $\quad$ w. $36 \frac{1}{8}$ inches

Collection of Metropolitan Museum of Art New York

26 


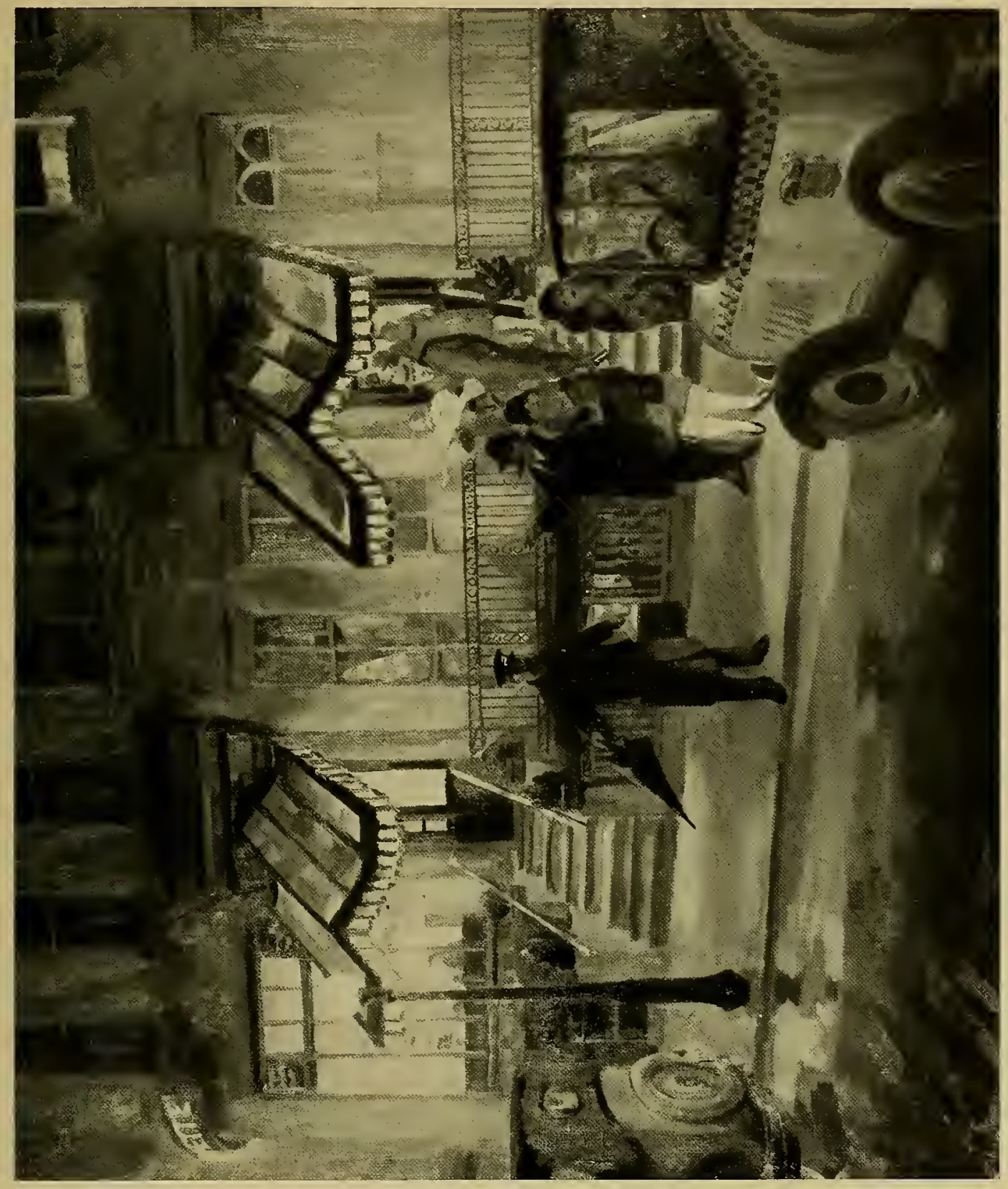


Reclining Nude, Extended Aria, 1927

H. 30 inches W. 40 inches 


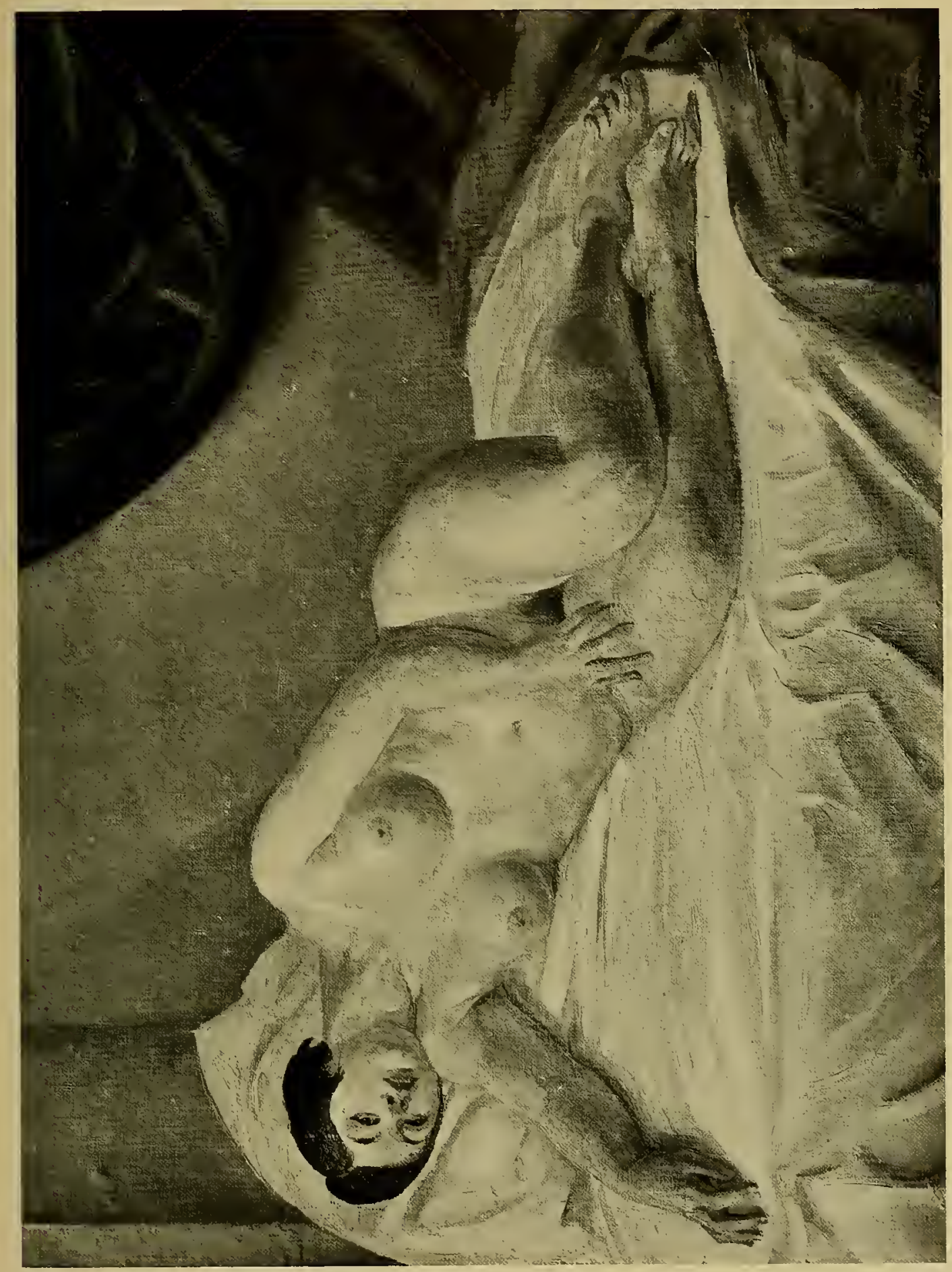


Littite Ranch House, 1926

H. 30 inches W. 40 inches

$3^{\circ}$ 


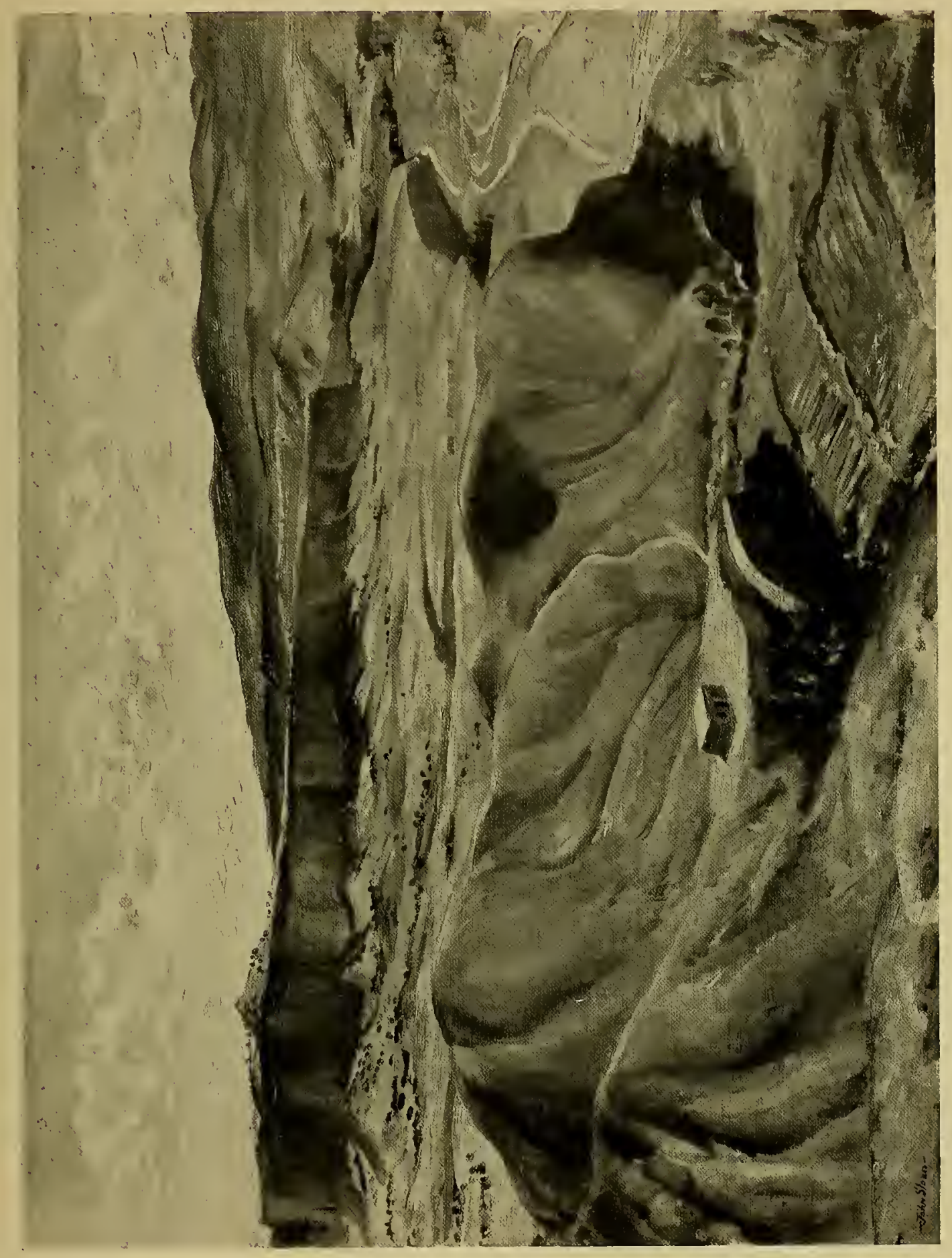


Plaza, SAnta Fé, EVEnING, 1920 H. 26 inches $\quad$ w. 32 inches Collection of Mr. Cyrus MIcCormick Chicago, Ill. 


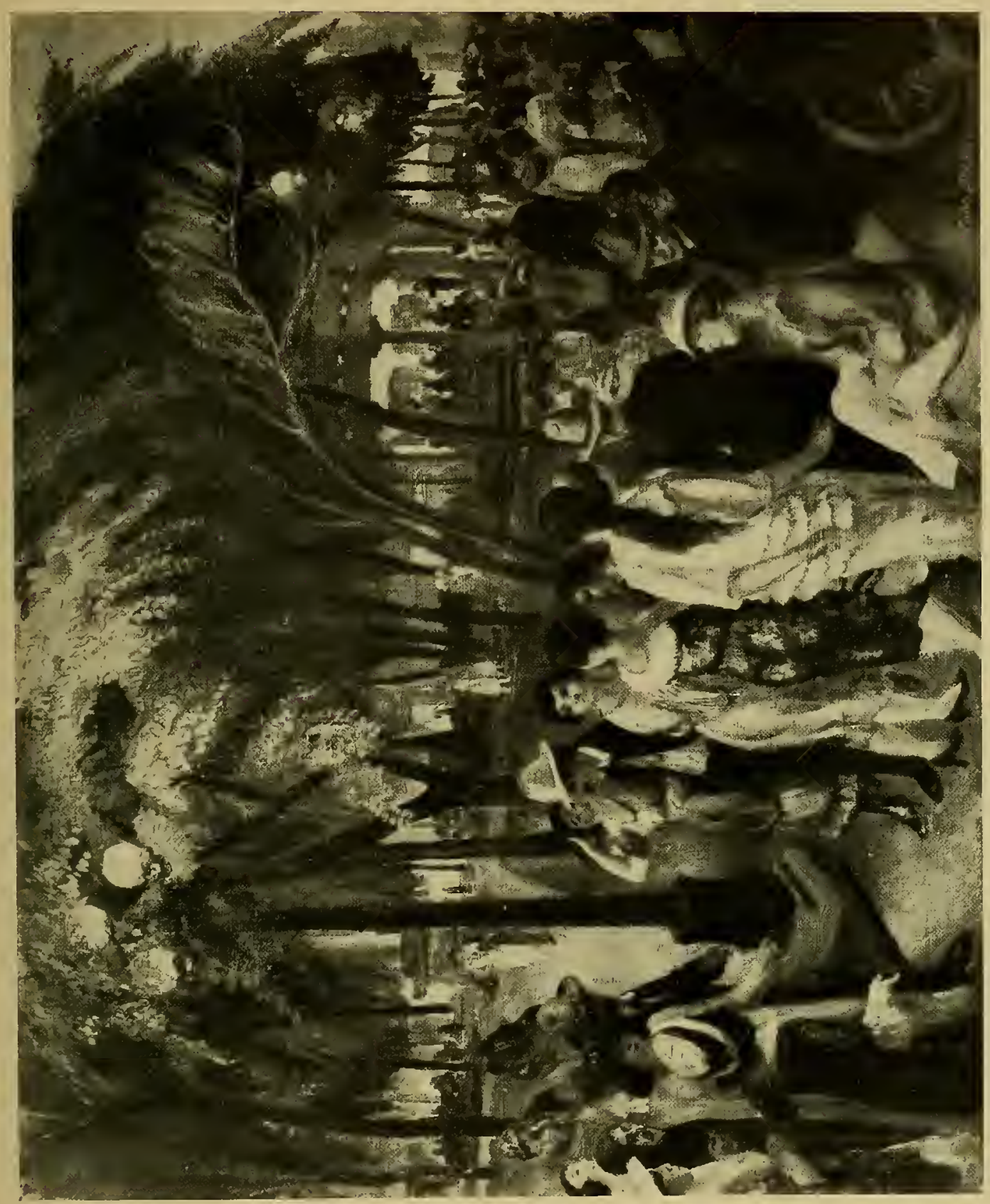


Renganeschi's, SATURDAY N' IGHT, 1912 H. 26 inches w. 32 inches

\section{Collection of Art Institute of Chicago}




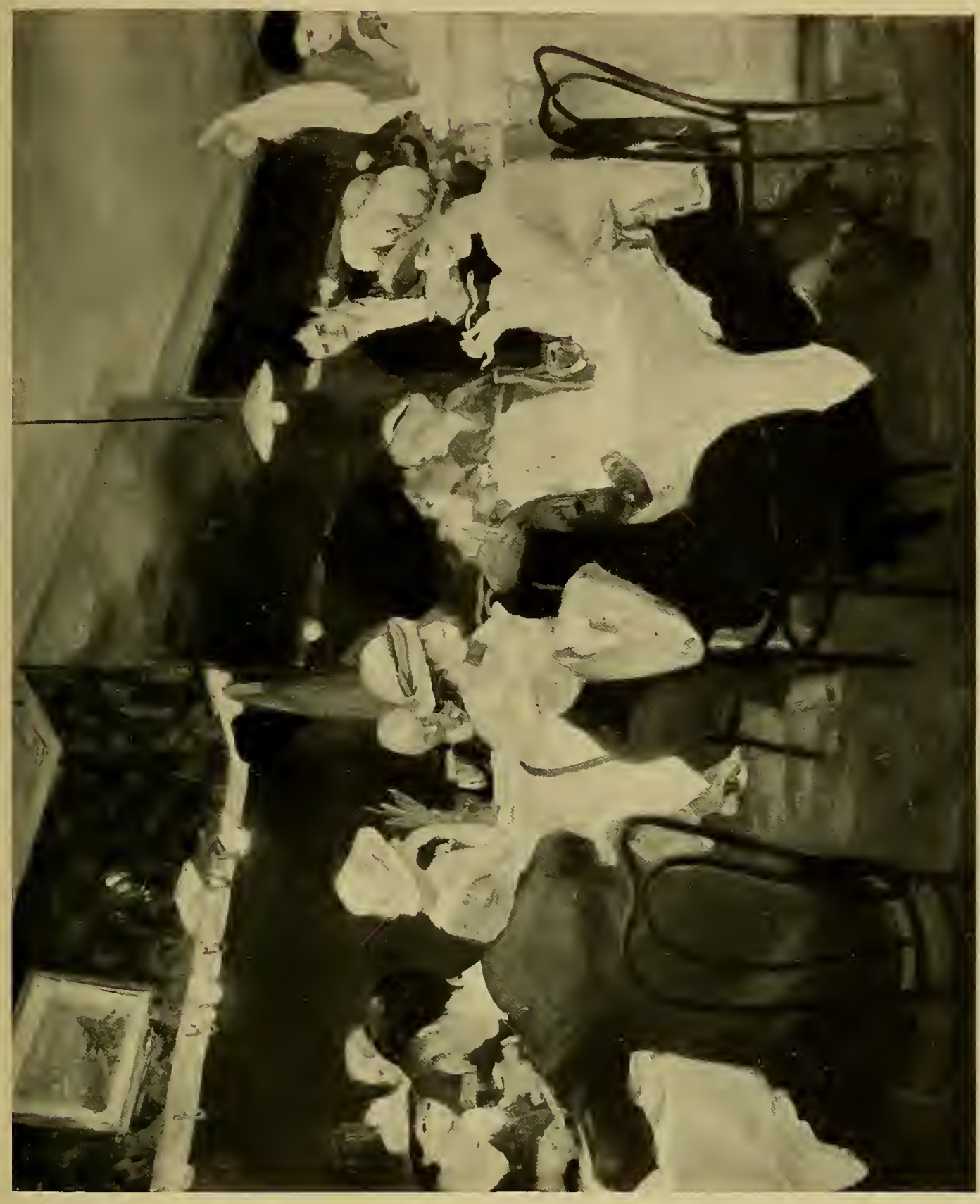


BACKYARDS, GREE NWICH VILLAGE, 1914 H. 26 inches W. 32 inches 


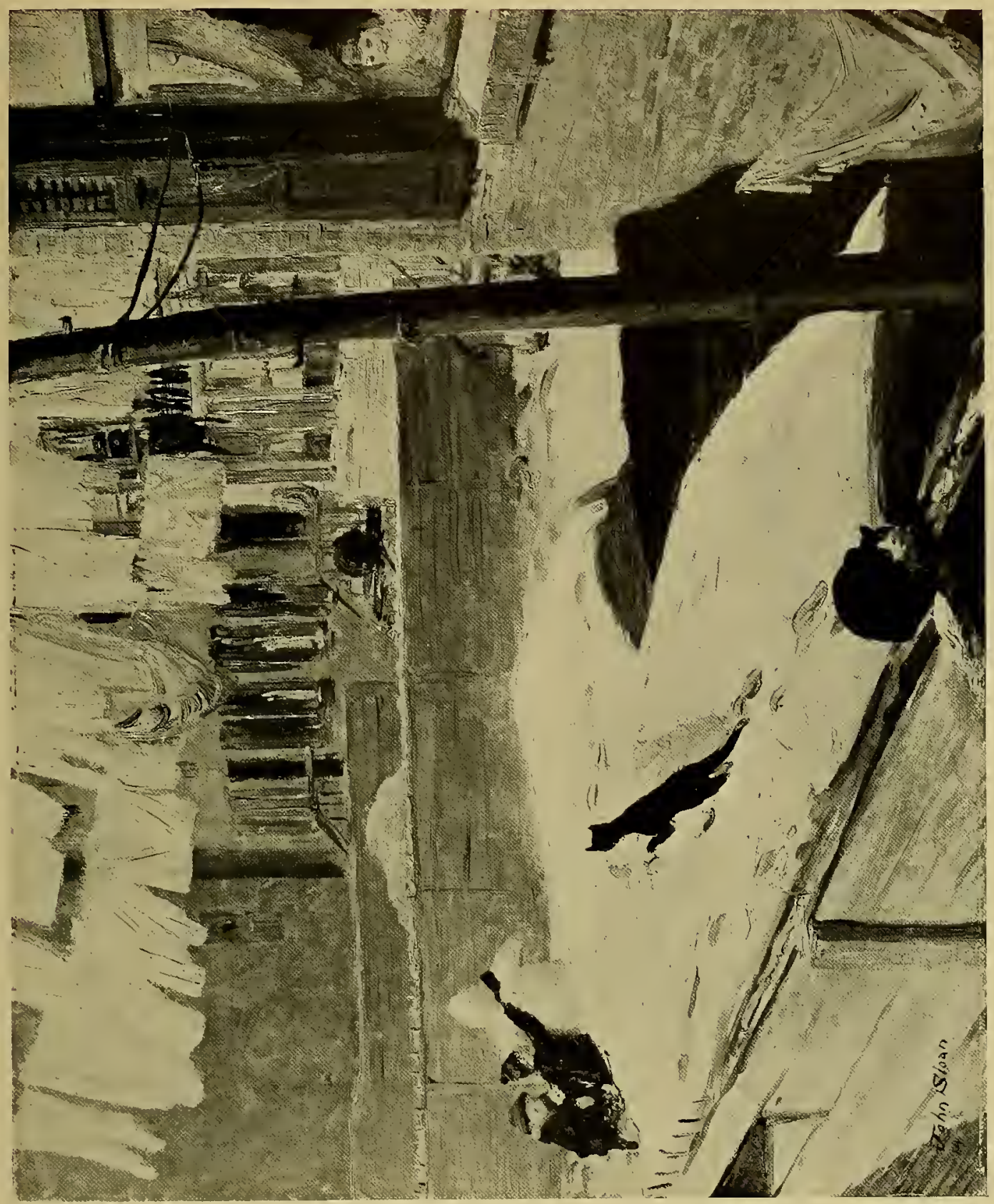


MCSORLEY'S BAR, 1912

$$
\text { H. } 26 \text { inches w. } 32 \text { inches }
$$

Collection of Detroit Institute of Arts

$3^{8}$ 


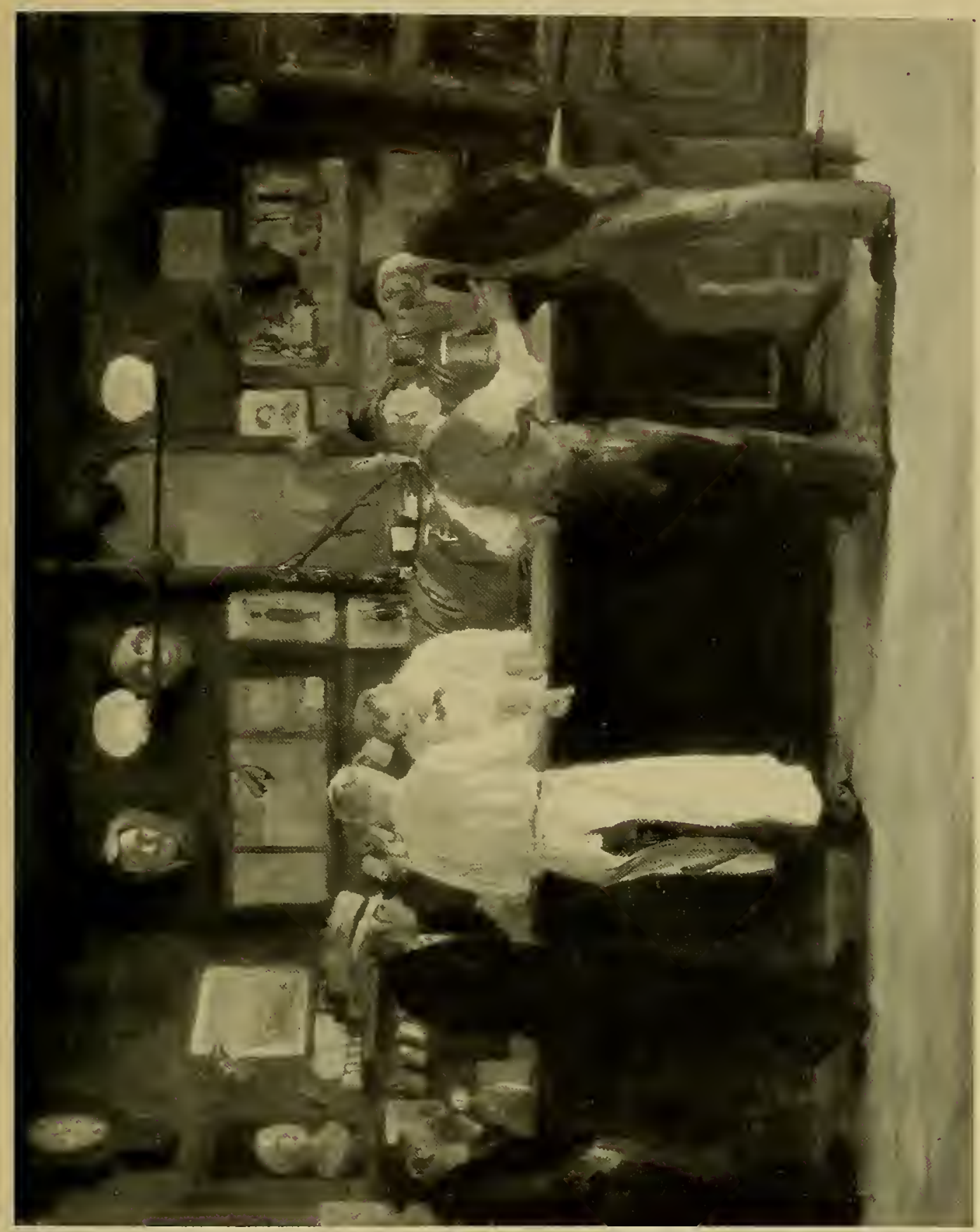


SPRING RAIN, 1912

H. $20 \frac{1}{4}$ inches W. 26 inches

Collection of Whitney Museum of American Art 


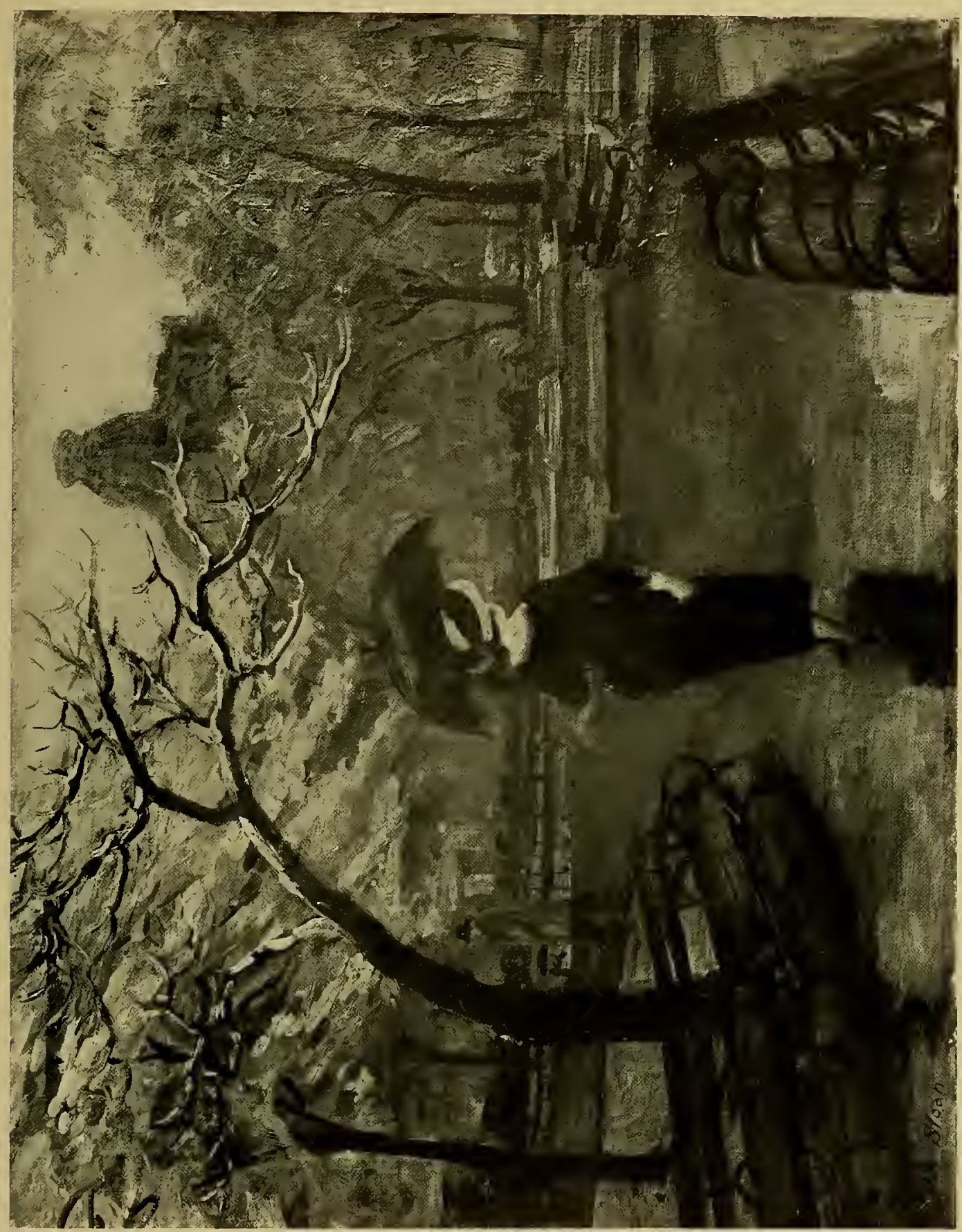


YeAts at PETItPAS, 1910

H. 26 inches $\quad$ w. 32 inches 


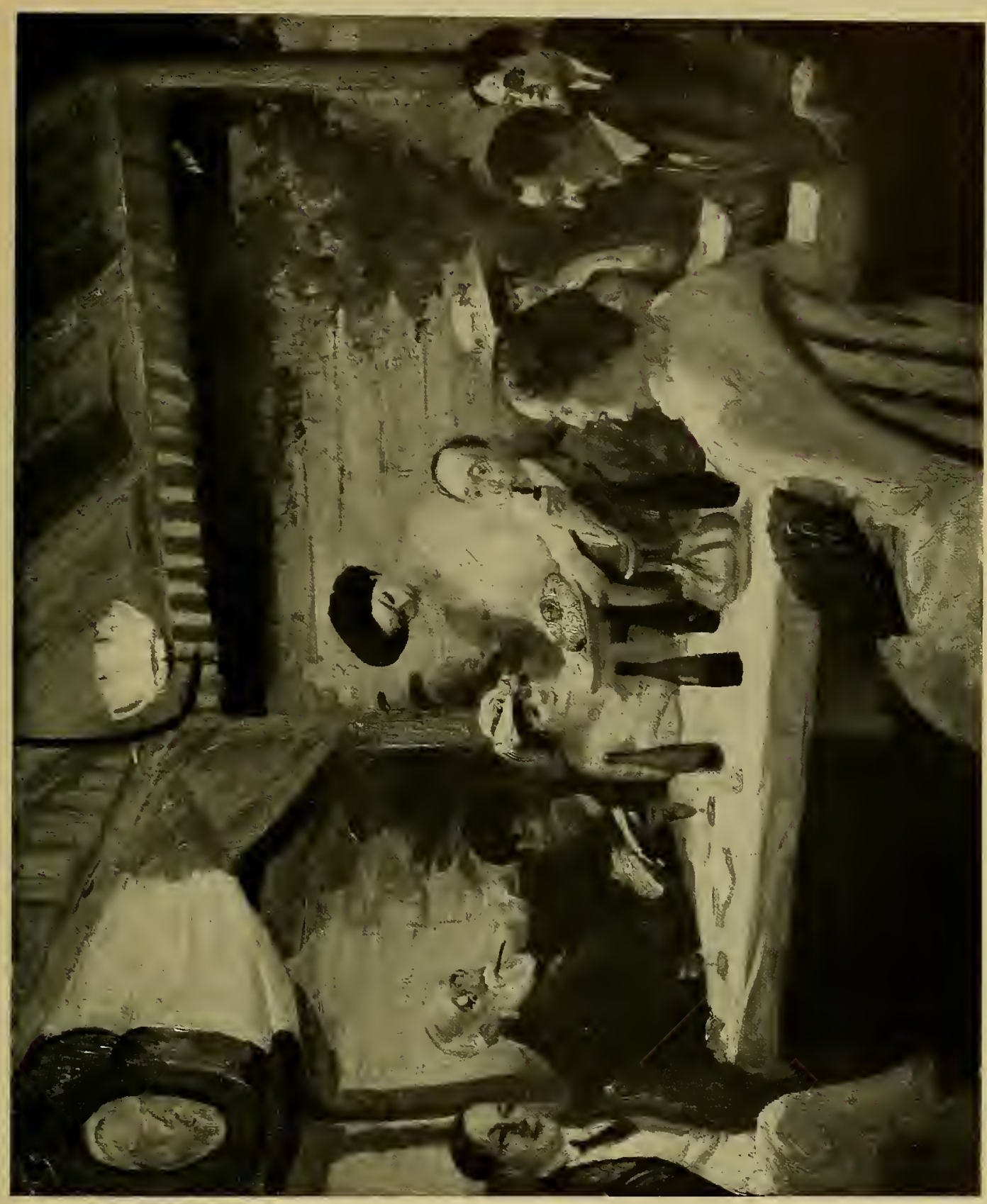


Dust Storm, Fifth AVEnue, i 906 H. 22 inches W. 27 inches

Collection of Metropolitan Museum of Art New York 


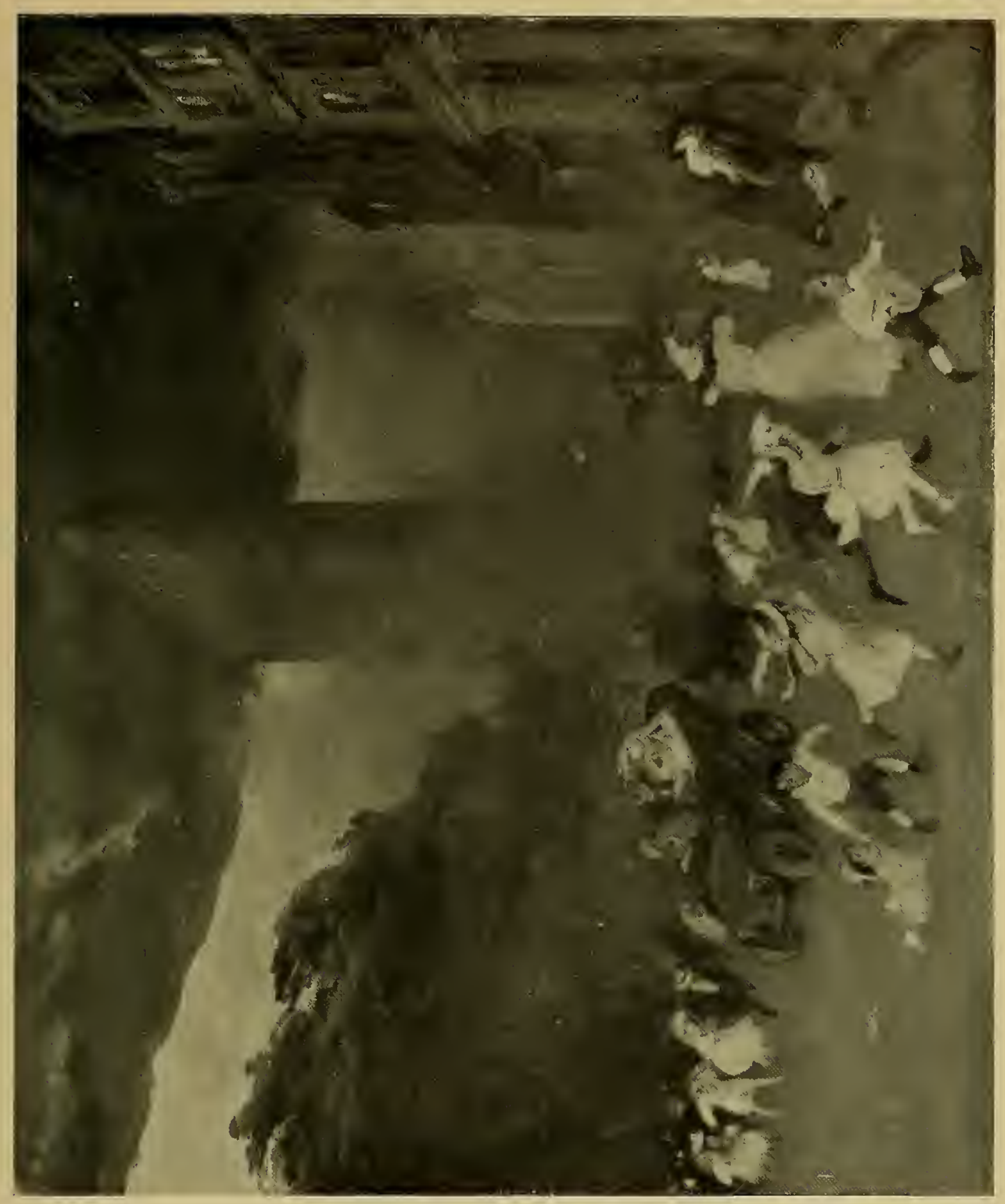


WAKE OF THE FERRY, 1907 H. 26 inches พ. 32 inches Collection of Phillips Memorial Gallery Washington, D.C. 


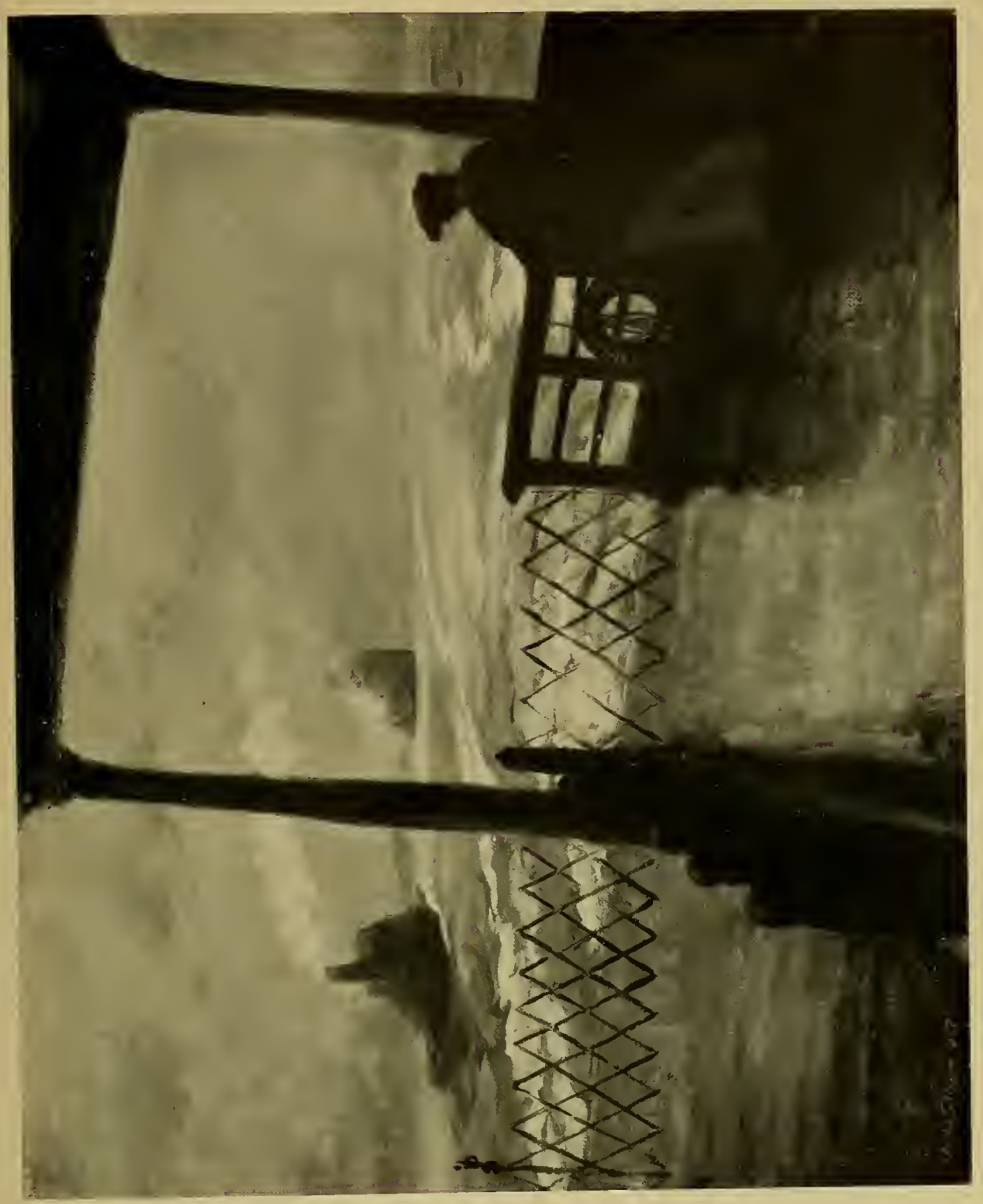


The Picnig Ground, 1907 H. 24 inches w. 36 inches 


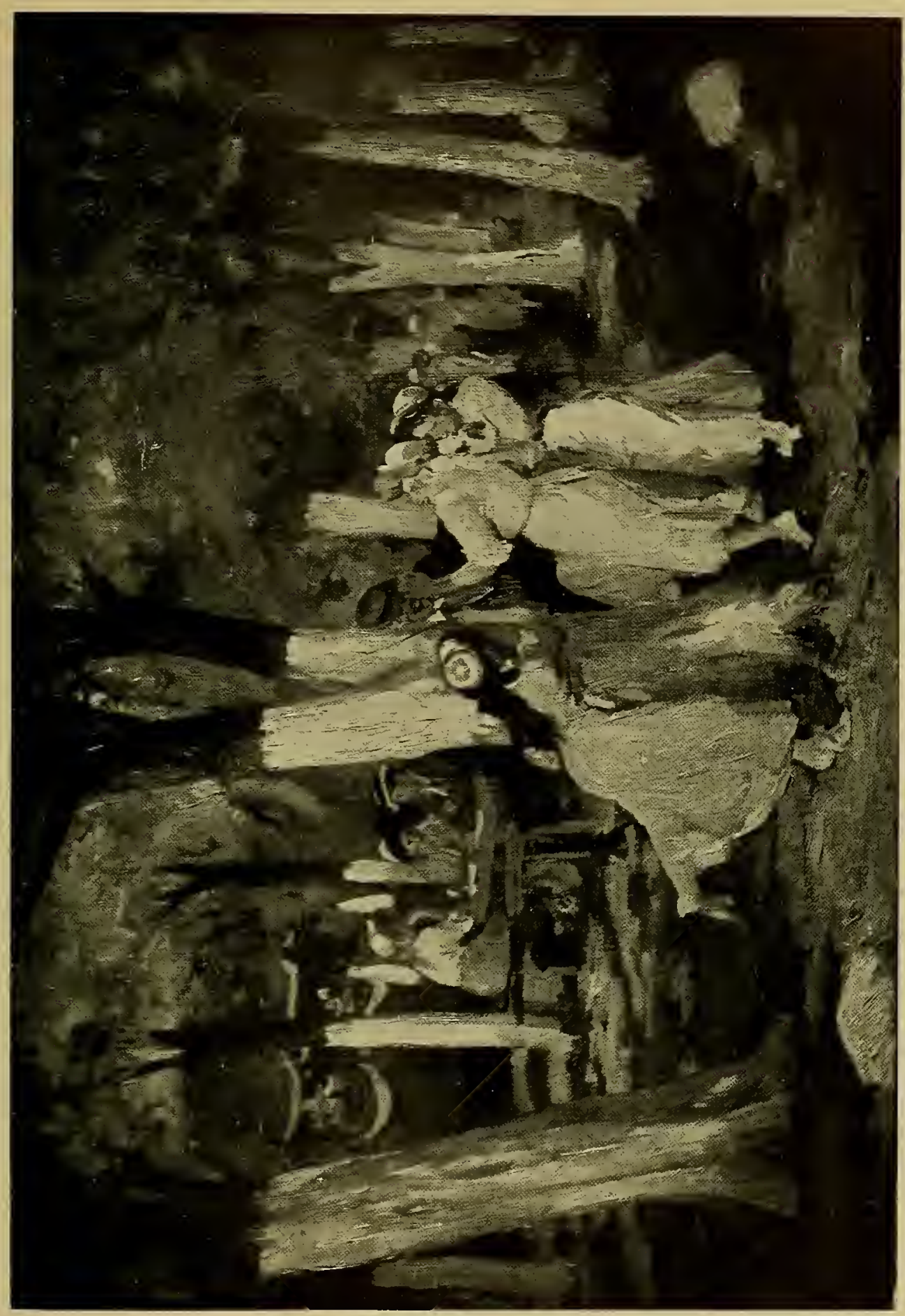


The Haymarket, 1907

H. 26 inches w. 32 inches 


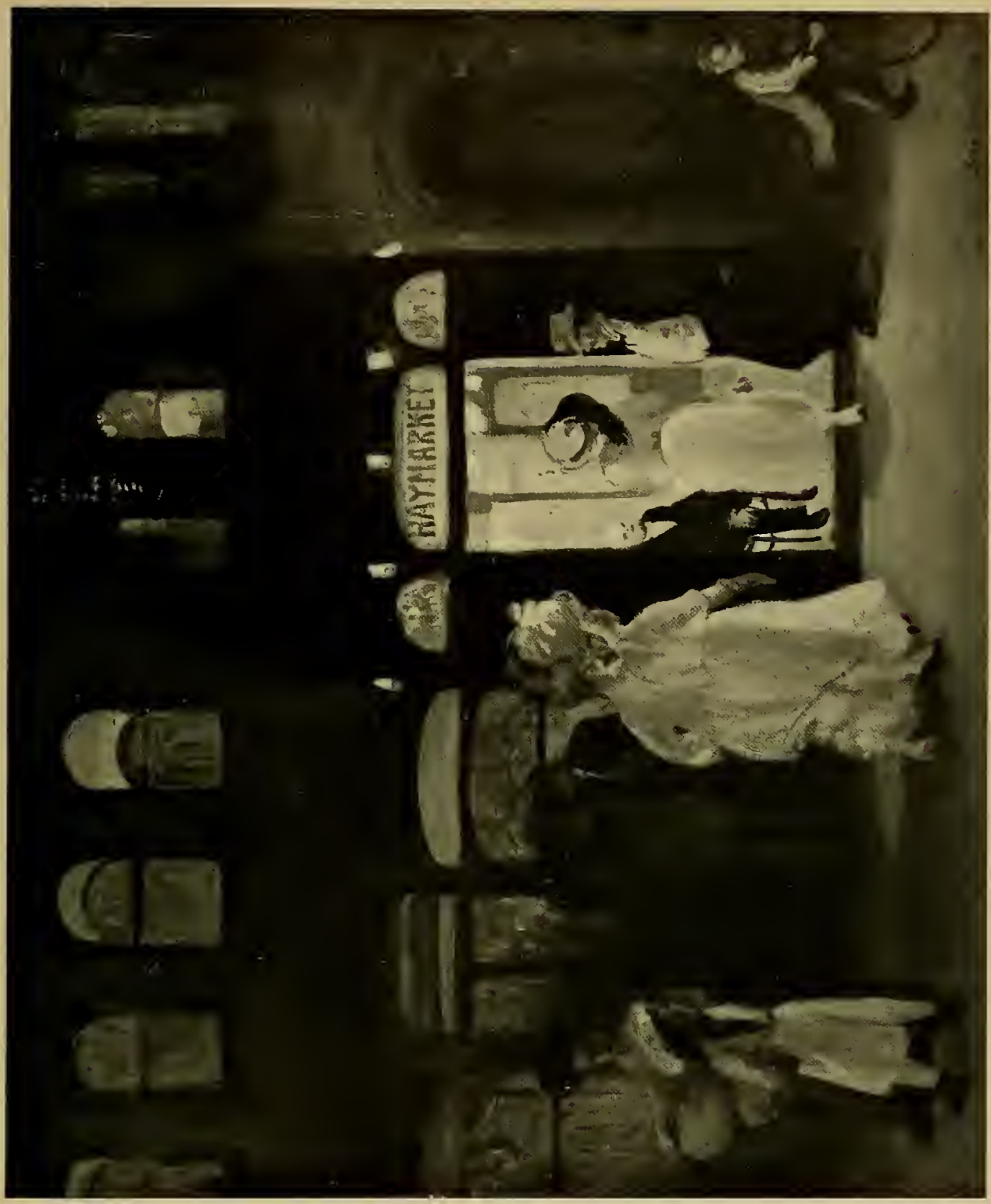


THREE A. M., 1909

H. 32 inches เ. 26 inches 


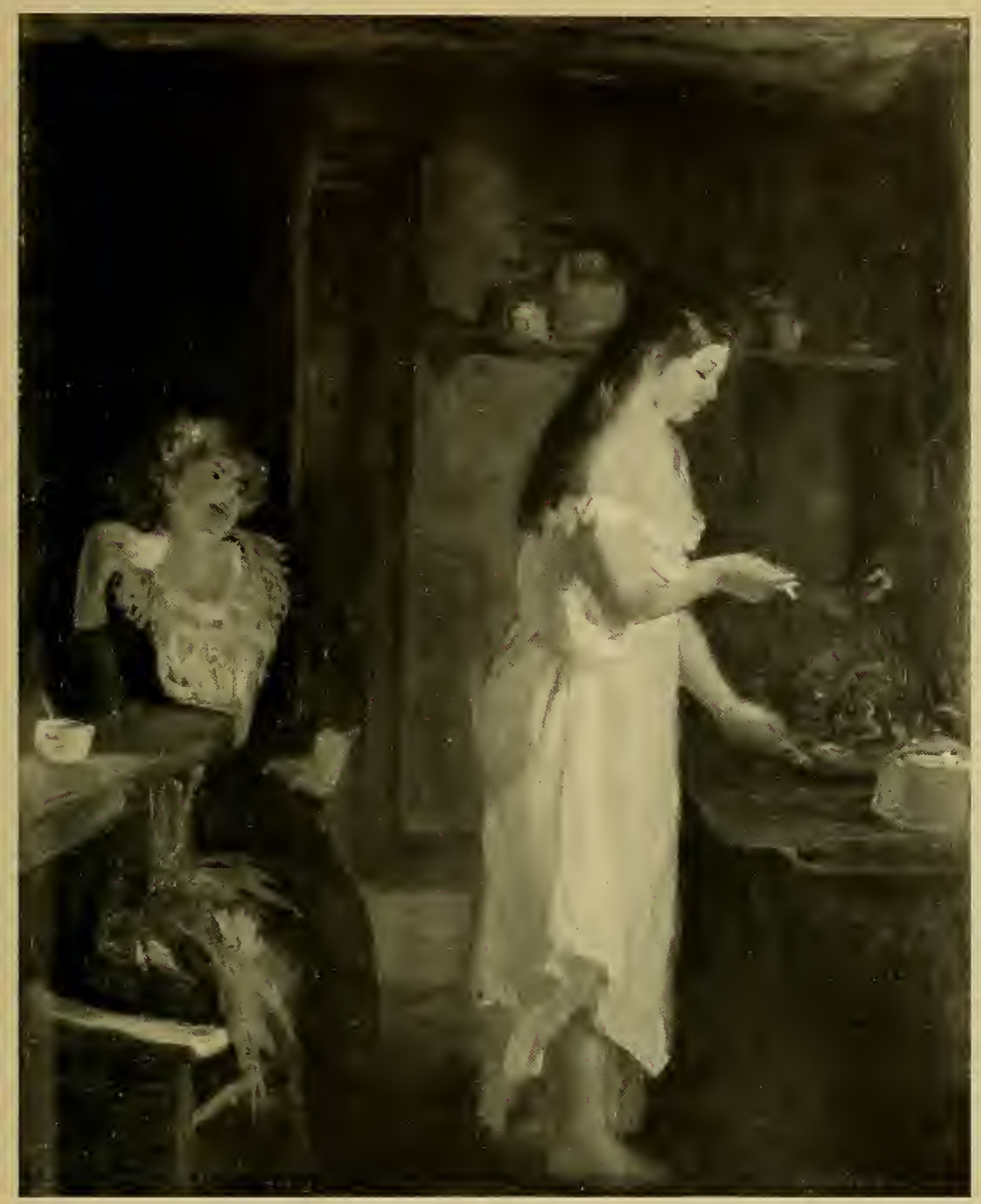


The Old Glown "Making UP," 1909

H. 32 inches w. 26 inches

Collection of Phillips Memorial Gallery

Washington, D.C. 


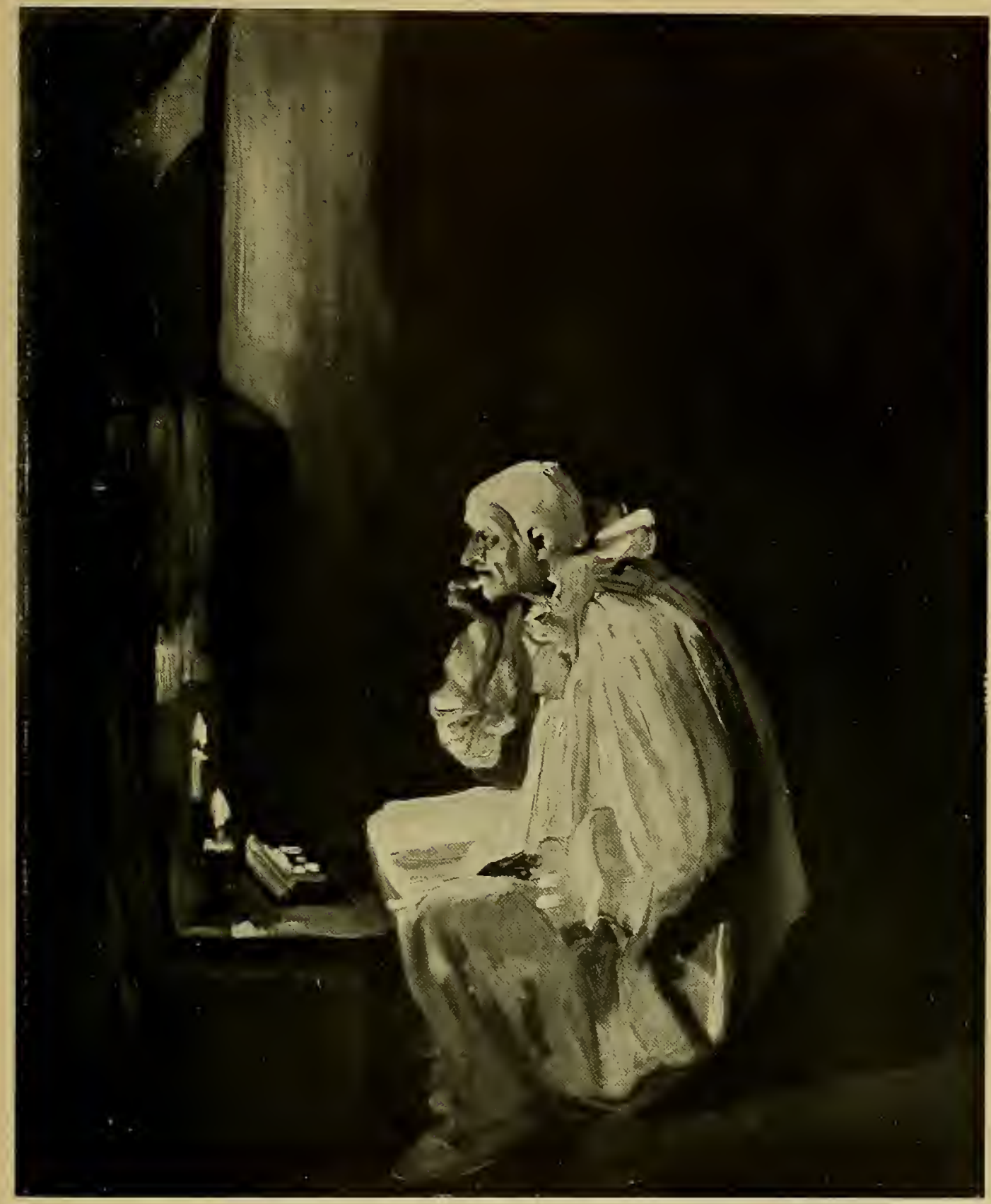


Boy With Pigcolo, 1904

H. 22 inches w. 27 inches

$5^{6}$ 


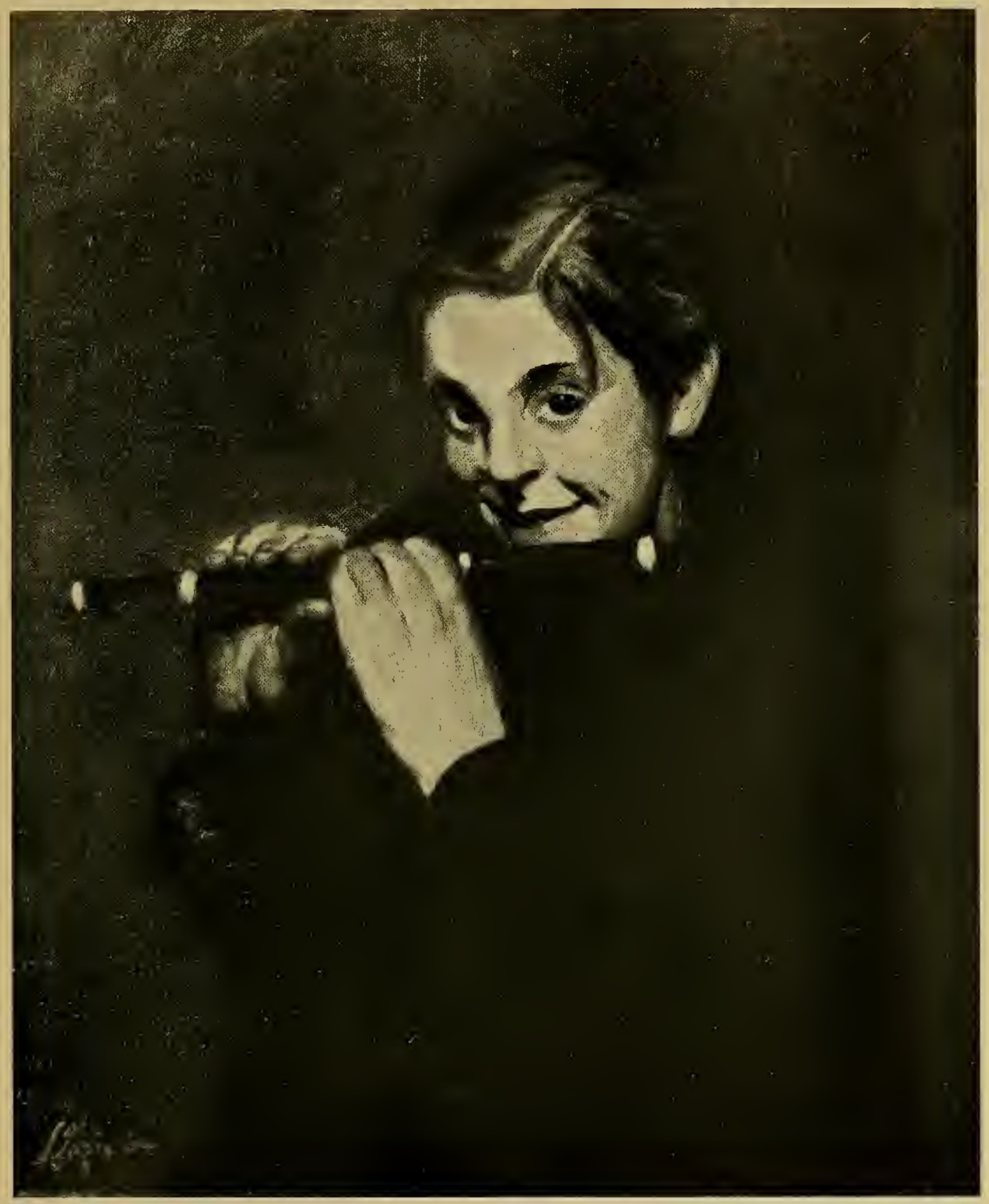




The Printing House of

William Edwin Rudge, Inc. NEW YORK CITY 

4 

SMITHSONIAN INSTITUTION LIBAARIES

||||||||||||||||||||||||||||||||||||||||||||||||

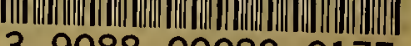

39088000800177 